\title{
METACOGNITIVE STRATEGY ON STUDENTS' LITERAL AND INFERENTIAL COMPREHENSION IN L2 READING
}

\author{
Ninda Oktaviana Putri ${ }^{\left.a^{*}\right)}$, Entis Sutisna ${ }^{\text {a) }}$, Asih Wahyuni a) \\ a) Universitas Pakuan, Kota Bogor, Indonesia \\ ${ }^{*}$ e-mail korespondensi: nindaputri1004@gmail.com
}

\section{Riwayat Artikel}

diterima 23 November 2021 direvisi 11 Desember 2021 disetujui 30 Desember 2021

\begin{abstract}
.
Reading is one skill that should be master by the students who want to learn English. However, students often find difficulties while learning English. To solve the problem, students should mastered four language English skills, and one of them is Reading. However, based on the preliminary data taken by the Researcher, it shows that students often did not know what they read. They are not aware of their own reading process. To solve this problem, the students need to know what kind of strategy that they should use while reading. The appropriate strategy that student should use when read is the metacognitive strategy. This paper entitled Metacognitive strategy on students' literal and inferential comprehension is conducted to know what kind of metacognitive strategy used on students' reading comprehension, especially their literal and inferential. The aims of this study are to know what kind of metacognitive strategy used on students' literal and inferential comprehension skills in L2 reading and how are the use of metacognitive strategy on students' literal and inferential comprehension to their reading skill. There were 3 strategy subscales or factors; Global Reading Strategies, ProblemSolving Strategies and Support Reading Strategies. Results revealed that participants reported frequent use the third metacognitive-strategy types stated by Mokhtari. K And Reichard. The method of this research is qualitative research. It takes place at Pakuan University. The population of this study were Fifth-semester students of the English language Education study program. While the sample of this research are students from class A and Class D that consists of 37 students. The technique and instruments of collecting data for this research are questionnaires, interviews, and forum group discussions. In conclusion, the result shows that the students use metacognitive strategy in their reading process.
\end{abstract}

Keywords: Metacognitive Strategy; Literal Comprehension; Inferential comprehension; Reading.

\section{STRATEGI METAKOGNITIF PADA PEMAHAMAN LITERAL DAN INFERENSIAL SISWA DALAM MEMBACA}

\begin{abstract}
Abstrak. Membaca merupakan salah satu keterampilan yang harus dikuasai oleh siswa yang ingin belajar bahasa inggris. Namun, siswa sering menemukan kesulitan saat belajar bahasa inggris. Untuk mengatasi masalah tersebut, siswa harus menguasai empat keterampilan bahasa inggris, dan salah satunya adalah Membaca. Namun berdasarkan data pendahuluan yang diambil oleh peneliti, menunjukkan bahwa siswa seringkali tidak mengetahui apa yang mereka baca. Mereka tidak menyadari proses membaca mereka sendiri. Untuk mengatasimasalah ini, siswa perlu mengetahui strategi seperti apa yang harus mereka gunakan saat membaca. Strategi yang tepatyang harus digunakan siswa dalam membaca adalah strategi metakognitif. Studi yang berjudul strategi metakognitif pada pemahaman literal dan inferensial siswa ini dilakukan untuk mengetahui strategi metakognitif seperti apa yang disunakan pada pemahaman membaca siswa, terutama pemahaman literal dan inferensial. Ada 3 tipe strategi metakognitif; Strategi membaca global, Strategi pemecahan masalah global, dan strategipendukung membaca. Hail mengungkapkan bahwa siswa menyatakan mereka sering menggunkan ketiga tipe strategi metakognitif yang dinyatakan oleh Mokhtari. K dan Rreichard. Tujuan penelitian ini adalah untuk mengetahui jenis strategi metakognitif yang digunakan pada keterampilan pemahaman literal dn inferensial siswa dalammembaca dan bagaimana penggunaan strategi metakognitif pada pemahaman literal dan inferensial siswa dalam keterampilan membaca mereka. Metode penelitian ini adalh penelitian kualitatif. Penelitian ini dilakukan di universitas Pakuan. Populasi dari penelitianini adalah mahasiswa pendidikan bahasa inggris semester 5 dari fdakultas keguruan dan pendidikan yang mengambil mata kuliah critical reading. Sampel penelitian ini adalah 37 siswa dari kelas A dan Kelas D. Tteknik dan instrumen pengambilan data dalam penelitian ini adalah angket, wawancara, dan juga diskusi kelompok.Kesimpulan dari penelitian ini dapat dinyatakan bahwa siswa memnggunakan strategi metakognitif dalam kegiatan membaca mereka
\end{abstract}

Kata Kunci: Strategi metakognitif; pemahaman literal; pemahaman inferensial; membaca.

\section{INTRODUCTION}

Reading skill is important because this will help students for effectively understand ideas delivered in written language. Reading itself has a meaningful understanding of a written text. It says that not only the reader should read throughout the whole text, however reading also about knowing and understanding the meaning that exists in the text.

It also showed, based on pre-observation by conducting interviews with some students who taken the critical reading class, they said that they did not read regularly because they often find it difficult to start reading. They said 
it is because they feel unmotivated to read because they often find the unknown vocabulary, they also said that the level of its passage also sometimes make they feel less motivated to read.

However, because of the lack of motivation of reading, data indicates that students exhibit low literal and inferential reading comprehension skills that hinder academic achievement. Its causes were low self-esteem and a lack of intrinsic motivation, poor recognition skills, limited vocabularies, a lack of activating prior knowledge, limited experiences, and a deficiency in understanding and using inferential thinking and reading comprehension strategies. It means that there is a need to find a strategy that will help the student learn English well. In other words, using an appropriate learning strategy might result in the success of study particularly in reading.

The strategy must contain the steps as well as the appropriate skills which fit well with the goal of learning reading itself. That is why the appropriate strategy is needed to learn English, especially reading.

Furthermore, the process of reading needs to include a range of language learning strategies. There are some types of language learning strategies. The strategies are designed to help the students to be able to read and understand reading passages well. Mc Namara (2009) states that strategies are essential, not only to successful comprehension, but also to overcoming reading problems and becoming a better reader. According to Richards \& Schmidt (2002), there are four types of language learning strategy, cognitive, metacognitive, management, and social strategy.

The strategy chosen in this study is Metacognitive strategy. Metacognitive strategy itself can be interpreted as a strategy that involves learning planning, thinking about learning processes, monitoring of production and understanding of a person and evaluation of learning after the activity is done. Louca (2008) in "Metacognition and Theory of Mind" points out that metacognition is a concept that has been used to refer to a variety of epistemological processes.

Through those statements, the researcher concludes that metacognitive strategy is the appropriate strategy for students' reading comprehension, especially their literal and inferential reading comprehension. In

In this research, the researcher finds out the problem in the process comprehension for students. The majority of them can read the text, but they find it difficult to comprehend the meaning of the text. Therefore, researcher will explore Metacognitive strategy that used in reading process especially like summarizing the students' literal and inferential comprehension in reading class.

\section{RESEARCH METHODOLOGY}

In conducting the research, the researcher applies qualitative approach and descriptive method to describe the learners' errors in writing the recount text. According to Creswell (2009: 37), a qualitative research is a method for exploring and understanding the meaning of the individuals or groups that comes from a social or human problem. It means that the descriptive method can be used in order to solve the problem on their research based on human cases that found.

\section{A. Forum Group Discussion}

The first data gathered use in this research is Forum Group Discussion. The Forum Group Discussion data gathered through Zoom meeting and will be delivered to find more information about metacognitive strategy use on students' literal and inferential comprehension in their reading process.

\section{B. Questionnaire Distribution}

Questionnaire is the second instrument. According to Creswell (2014: 142), "Questionnaire has two types of questions; open ended question and close ended question." In this research close question questionnaire will be distributed to all participants.

\section{Interview}

Interview is the last instrument that is used in collecting the data of this research. As affirmed by Creswell (2014: 330) the goal of interview is to get theoverview and the opinion of the participants taught. Therefore, from the interview the researcher will get information from the participants' opinion related to learners' errors in writing the recount text. The process of the interview will be recorded by the researcher. Semi-unstructured interview will be applied in this research as the interview model. According to Creswell (2014: 254), "Semi-unstructured interview is made to figure out participants perception and opinion."

\section{Data Analysis}

In conducting this research, the researcher used forum group discussion, questionnaire and interview. The FGD was used as the supporting instrument in this research after taking the result of questionnaire and interview. After getting data from students answer from the discussion researcher will distribute the questionnaire to the students to get additional information and data related to the strategy that used while reading-process.

In this research, questionnaire used to get additional information related to students' knowledge of strategy that they use while reading and also to get information abiout their understanding of Literal and inferential aspects through reading process. The questionnaire consisting of ten questions and the form of questions was multiple choices which consisted of three options in each question.

The last step is an interview. To collect more information from the participants, the researcher will use audio recorder to record the interview that happened between the researcher and the participant. The researcher will conduct interviews through Whatsapp phone-call and the transcption will be recorded by audio recorder. The interview is conducted to get the students' opinion about Metacognitive strategy that they use while reading and also to get information whether the strategy itself have any connection to their literal and inferential comprehension during reading process. 


\section{DATA DESCRIPTION}

\section{A. Data from Questionnaire}

In this research, close-ended questionnaire was used to gain more data about metacognitive strategy used on students literal and inferential comprehension in Critical Reading class. This questionnaire contains statements that are structured to obtain the responses from the participants towards the research question. The questionnaire was distributed through Google form to 37 participants. It consists of 15 questions with three indicators. Those indicators are students' understanding of the use of Metacognitive Strategy, students' strategy step in reading, and students' knowledge about literal and inferential aspect in text. Since this questionnaire used rating scale then there are four options to choose. They are never, rarely, always, and often.

TABEL 1. Result of Questionaire

\begin{tabular}{|c|c|c|c|c|}
\hline No & Statement & $\begin{array}{c}\text { Alternati } \\
\text { ve answer }\end{array}$ & $\begin{array}{c}\text { Frequenc } \\
\mathbf{y}\end{array}$ & $\begin{array}{c}\text { percentag } \\
\mathrm{e}\end{array}$ \\
\hline \multirow[t]{4}{*}{1} & $\begin{array}{ll}\text { Saya } & \text { selalu } \\
\text { dapat }\end{array}$ & $\begin{array}{l}\text { Tidak } \\
\text { pernah }\end{array}$ & 0 & 0 \\
\hline & memahami isi & Jarang & 11 & $29,8 \%$ \\
\hline & dari teks yang & Sering & 23 & $62,1 \%$ \\
\hline & saya baca. & Selalu & 3 & $8,1 \%$ \\
\hline \multirow[t]{4}{*}{2} & $\begin{array}{lr}\text { Ketika } & \text { saya } \\
\text { kesulitan } & \text { saat }\end{array}$ & $\begin{array}{l}\text { Tidak } \\
\text { pernah }\end{array}$ & 0 & 0 \\
\hline & memahami teks, & Jarang & 2 & $5,4 \%$ \\
\hline & saya membaca & Sering & 20 & $54,1 \%$ \\
\hline & $\begin{array}{l}\text { kembali teks } \\
\text { tersebut untuk } \\
\text { mendapatkan } \\
\text { informasi lebih } \\
\text { dalam lagi }\end{array}$ & Selalu & 15 & $40,5 \%$ \\
\hline \multirow[t]{4}{*}{3} & $\begin{array}{l}\text { Saya } \\
\text { menggunakan }\end{array}$ & $\begin{array}{l}\text { Tidak } \\
\text { pernah }\end{array}$ & 0 & 0 \\
\hline & strategi dalam & Jarang & 16 & $43,2 \%$ \\
\hline & kegiatan & Sering & 19 & $51,4 \%$ \\
\hline & membaca. & Selalu & 2 & $5,4 \%$ \\
\hline \multirow[t]{4}{*}{4} & $\begin{array}{lr}\text { Saya } & \text { merasa } \\
\text { terbantu } & \text { saat }\end{array}$ & $\begin{array}{l}\text { Tidak } \\
\text { pernah }\end{array}$ & 0 & 0 \\
\hline & menerapkan & Jarang & 7 & $19 \%$ \\
\hline & strategi dalam & Sering & 24 & $64,8 \%$ \\
\hline & $\begin{array}{l}\text { kegiatan } \\
\text { membaca }\end{array}$ & Selalu & 6 & $16,2 \%$ \\
\hline \multirow[t]{9}{*}{5} & $\begin{array}{l}\text { Setelah kegiatan } \\
\text { membaca }\end{array}$ & $\begin{array}{l}\text { Tidak } \\
\text { pernah }\end{array}$ & 1 & $2,7 \%$ \\
\hline & selesai, saya & Jarang & 13 & $35,1 \%$ \\
\hline & mengevaluasi & Sering & 20 & $54,1 \%$ \\
\hline & $\begin{array}{l}\text { kembali terkait } \\
\text { terkait informasi }\end{array}$ & Selalu & 3 & $8.1 \%$ \\
\hline & yang telah & & & \\
\hline & $\begin{array}{l}\text { ditemukan saat } \\
\text { membaca untuk }\end{array}$ & & & \\
\hline & kemudian & & & \\
\hline & membuat & & & \\
\hline & $\begin{array}{l}\text { kesimpulan dari } \\
\text { teks yang saya } \\
\text { baca }\end{array}$ & & & \\
\hline \multirow[t]{4}{*}{6} & Saya melakukan & Tidak & 1 & $2,7 \%$ \\
\hline & 'note taking' & pernah & & \\
\hline & saat membaca & Jarang & 11 & $29,8 \%$ \\
\hline & untuk & Sering & 19 & $51,3 \%$ \\
\hline
\end{tabular}

\begin{tabular}{|c|c|c|c|c|}
\hline No & Statement & $\begin{array}{l}\text { Alternati } \\
\text { ve answer }\end{array}$ & $\begin{array}{c}\text { Frequenc } \\
\mathbf{y}\end{array}$ & $\begin{array}{c}\text { percentag } \\
\text { e }\end{array}$ \\
\hline & $\begin{array}{l}\text { membantu saya } \\
\text { mengingat apa } \\
\text { yang saya baca. }\end{array}$ & Selalu & 6 & $16,2 \%$ \\
\hline \multirow[t]{4}{*}{7} & $\begin{array}{l}\text { Setelah } \\
\text { membaca, Saya }\end{array}$ & $\begin{array}{l}\text { Tidak } \\
\text { pernah }\end{array}$ & 1 & $2,7 \%$ \\
\hline & membuat & Jarang & 11 & $29,8 \%$ \\
\hline & kesimpulan dari & Sering & 22 & $59,4 \%$ \\
\hline & $\begin{array}{l}\text { informasi yang } \\
\text { telah ditemukan } \\
\text { di teks. }\end{array}$ & Selalu & 3 & $8,1 \%$ \\
\hline \multirow[t]{4}{*}{8} & $\begin{array}{l}\text { Saya menebak } \\
\text { makna dari kata }\end{array}$ & $\begin{array}{l}\text { Tidak } \\
\text { pernah }\end{array}$ & 2 & $5,4 \%$ \\
\hline & baru dengan & Jarang & 8 & $21,6 \%$ \\
\hline & menghubungkan & Sering & 23 & $62,1 \%$ \\
\hline & $\begin{array}{l}\text { dengan kalimat } \\
\text { yang muncul } \\
\text { sebelum } \\
\text { ataupun sesudah } \\
\text { kata tersebut di } \\
\text { dalam teks. }\end{array}$ & Selalu & 4 & $10,9 \%$ \\
\hline \multirow[t]{4}{*}{9} & $\begin{array}{l}\text { Saya merasa } \\
\text { kesulitan saat }\end{array}$ & $\begin{array}{l}\text { Tidak } \\
\text { pernah }\end{array}$ & 1 & $2,7 \%$ \\
\hline & menemukan & Jarang & 5 & $13,6 \%$ \\
\hline & kalimat yang & Sering & 26 & $70,1 \%$ \\
\hline & $\begin{array}{l}\text { saya tidak } \\
\text { pahami ketika } \\
\text { membaca. }\end{array}$ & Selalu & 5 & $13,6 \%$ \\
\hline 10 & $\begin{array}{l}\text { Ketika saya } \\
\text { tidak } \\
\text { mengetahui arti } \\
\text { dari kata di } \\
\text { dalam teks, saya } \\
\text { menggunakan } \\
\text { informasi yang } \\
\text { telah saya } \\
\text { dapatkan } \\
\text { sebelumnya } \\
\text { untuk menebak } \\
\text { makna dari kata } \\
\text { tersebut }\end{array}$ & $\begin{array}{l}\text { Tidak } \\
\text { pernah }\end{array}$ & 0 & 0 \\
\hline \multirow[t]{4}{*}{11} & $\begin{array}{l}\text { Saya menebak } \\
\text { 'main idea' dari }\end{array}$ & $\begin{array}{l}\text { Tidak } \\
\text { pernah }\end{array}$ & 0 & 0 \\
\hline & keseluruhan teks & Jarang & 9 & $24,2 \%$ \\
\hline & berdasarkan dari & Sering & 24 & $64,9 \%$ \\
\hline & $\begin{array}{l}\text { kata kunci yang } \\
\text { ditemukan di } \\
\text { dalam teks. }\end{array}$ & Selalu & 4 & $10,9 \%$ \\
\hline \multirow[t]{4}{*}{12} & $\begin{array}{l}\text { Saya } \\
\text { menggambarkan }\end{array}$ & $\begin{array}{l}\text { Tidak } \\
\text { pernah }\end{array}$ & 0 & 0 \\
\hline & visualisasi dari & Jarang & 6 & $16,2 \%$ \\
\hline & peristiwa yang & Sering & 26 & $70,1 \%$ \\
\hline & $\begin{array}{l}\text { terjadi di dalam } \\
\text { teks kedalam } \\
\text { pikiran saya. }\end{array}$ & Selalu & 5 & $13,6 \%$ \\
\hline \multirow[t]{4}{*}{13} & $\begin{array}{l}\text { Saya mencoba } \\
\text { untuk }\end{array}$ & $\begin{array}{l}\text { Tidak } \\
\text { pernah }\end{array}$ & 0 & 0 \\
\hline & menafsirkan & Jarang & 9 & $24,2 \%$ \\
\hline & maksud dan & Sering & 25 & $67,7 \%$ \\
\hline & $\begin{array}{l}\text { tujuan penulis } \\
\text { menuliskan teks } \\
\text { yang saya baca. }\end{array}$ & Selalu & 3 & $8,1 \%$ \\
\hline 14 & $\begin{array}{l}\text { Saya sering } \\
\text { berhenti sejenak }\end{array}$ & $\begin{array}{l}\text { Tidak } \\
\text { pernah }\end{array}$ & 0 & 0 \\
\hline
\end{tabular}




\begin{tabular}{lllll}
\hline No & \multicolumn{1}{c}{ Statement } & $\begin{array}{c}\text { Alternati } \\
\text { ve answer }\end{array}$ & $\begin{array}{c}\text { Frequenc } \\
\text { y }\end{array}$ & $\begin{array}{c}\text { percentag } \\
\text { e }\end{array}$ \\
\hline & saat membaca & Jarang & 7 & $18,9 \%$ \\
untuk & Sering & 24 & $64,9 \%$ \\
menganalisis & Selalu & 6 & $16,2 \%$ \\
informasi yang & & & \\
telah ditemukan & & & \\
di dalam teks & & & \\
Saat kegiatan & Tidak & 1 & $2,7 \%$ \\
membaca & pernah & & \\
berlangsung, & Jarang & 9 & $24,2 \%$ \\
Saya sering & Sering & 23 & $52,1 \%$ \\
bertanya kepada & Selalu & 4 & $10,9 \%$ \\
diri sendiri [self- & & & \\
questioning] & & & \\
ketika & & & \\
menemukan & & & \\
pertanyaan & & \\
terkait teks & & \\
untuk & & \\
menganalisis & & \\
dan memikirkan \\
pertanyaan \\
tersebut.
\end{tabular}

\section{B. Data from Interview}

The second data was from interview. There are eight participants who were interviewed through WhatSapp voice note. It was done to gain further information related to the research. There were six questions which were divided into three indicators. The indicators were Students' knowledge about metacognitive strategy, students' metacognitive step in their reading process, and students' knowledge of literal and inferential aspects of the text

\section{1) Students understanding about metacognitive strategy}

Question number one of the interview is about the extent of strategy can help the participant while reading. It was found out that most of the participants find the use of strategy is helpful. It can be seen based on the statement of R\#6 and R\#7 in excerpt \#1.

\section{Excerpt \#1}

R\#7 : ...membantu seseorang untuk memahami bacaan tersebut...

[... Help someone to understand the text..]

R\#6: Penerapan strategi dalam membantu kegiatan membaca itu menurut saya ee amat sangat dibutuhkan. Karena dalam membaca kita membutuhkan strategi yang mana gunanya untuk memudahkan kita dalam memahami sebuah bacaan...

[ The implemention of strategy for me is really needed. Because in reading, we need strategy to make it easier for us to understand the text...]

In the second question the researcher asked whether they found the benefits of using metacognitive strategy. Most of students agree that they can see benefits of using metacognitive strategy. It can be seen in excerpt\#2 by statement from R\#2

\section{Excerpt \#2}

R\#2 : iya saya merasakan adanya manfaat dari startegi tersebut ketika saya ee sedang membaca sebuah artikel jurnal yang sangat panjang.

[ I can feel the benefit of those strategy when I ee read a journal which very long indeed]

\section{2) Students metacognitive strategy step in reading}

The third question was about to find how the participants use the three step of metacognitive to their reading process which are planning, monitoring, and evaluating. It was found that the participants mostly use predicting, underlining, note-taking and summarizing as they read the text. It can be proven by statement from R\#2 and R\#5

Excerpt \#3

R\#2 : ..saya menandainya menggunakan stabilo berwarna..

[I mark it by using a colorful highlighter]

R\#5 : ...saya menggunakan predicting yang mana saya harus liat judul dimana biasanya mencakup garis besar dari seluruh informasi...

[I use predicting where I should see the title which usually show the whole information]

The forth question is talking about whether the strategy that they used are effective or not when they did the reading process. Mostly all of participants agree that they know whether the strategy they used are effective through the time they spent while reading. It can be seen by the statement from R\#1 in Excerpt \#6

\section{Excerpt \#4}

R\#1 ‥itu terlihat dari setting waktunya. Saat menggunakan strategi tersebut saya lebih cepat mendapatkan informasi...

[it can be seen from the timing. When I used those strategy, I spent less time to get the information]

3) Students knowledge about literal and inferential aspect on the text

The fifth question was asked to gain information about how participants make a conclusion based on the information that they already found while they read. They said that they make a conclusion from the keyword that they have found on the text.

\section{Excerpt \#5}

$R \# 6$ : saya menandai informasi yang penting. Kemudian, saya akan ubah ee infromasi yang penting tersebut kedalam bahasa saya sendiri kemudian saya jadikan satu menjadi kesimpulan.

[ I mark the important information then I will ee change to my own language then I will put it together become a conclusion.

the sixth question was about to know how the students handle their difficulties toward unknown word that they find while they read. Some students faced their difficulty by rereading their sentences on the text and looking up in the internet.

\section{Excerpt \#6}

$R \# 2 \quad \therefore$ untuk mencari tau artinya lalu saya membaca kembali..

[.. to find the meaning then I re-read again..] 


\section{Data from Forum Group Discussion}

The data were taken from students' discussion on Forum group discussion which held through online panel discussion on Zoom application. There are two respondents who participated in Forum Group Discussion. In this forum group discussion the students and the interviewer were discussing about six question that related to the writers' research which is metacognitive strategy on students' literal and inferential comprehension in 12 reading

The first question was talking about their strategy to collect the information that they already found on the text while reading process happened.

\section{Excerpt \#1}

Narasumber 1 : mm.. saya biasanya mengumpulkan informasi dilakukan dengan cara teknik skimming dan scanning.

[ I used to collect the data by using skimming and scanning. ]

Narasumber 2 : ...Jadi pas lagi ngumpulin informasi, aku suka bolak balik ke teks dan paragraphnya lagi buat mastiin masih ada informasi yang belum kebaca atau gimana gitu

[so, when I collect the data, I often going back and forth in text and the paragraph to make sure whether there are still information that I skipped..]

The second question is talking about inferential comprehension which is how the handle and answer the questions whose answers do not appear in the text and require their own analysis to answer it.

Excerpt \#2

Narasumber 1: .. melihat main idea atau ide utama penulis pada teks saya bisa mendapatkan informasi yang tidak tercantum didalam teks, setelah itu saya akan menggunakan informasi dari main idea untuk menganalisis pertanyaan seperti itu

[... looking at the the writers' main idea on the text I can find the information that is not appear on the text, then I will use the information from main idea to analyze the question]

Narasumber 2 : kalau ulvi biasanya bacanya di abstrack biasanya mencantumkan kata kunci dari tujuan si teks .. Ada juga baca keseluruhan teks.

[..for me, I used to read the abstrack used to listed the keyword from the goal of the text]

The third question is what are the students' opinion whether readers need to setting the goals and purpose for their own reading process.

\section{Excerpt \#3}

Narasumber 1 :... jadi kalo untuk aku aku harus bisa dapet jawaban yang bener jadi aku membaca berulang kali harus supaya dapat jawaban yang tepat. Gitu

[.. for me, I should get the correct answer so I re-reading the text again to get the answer pcisely]

Narasumber 2 : ...Aku juga baca untuk meningkatkan kemampuan pemahaman membaca aku aku biasanya selalu mengevaluasi kegiatan membaca aku sih kak, biar aku tau apakah aku udah ada improve atau belum. Terus juga bisa mengoreksi kesalahan aku yang sebelumsebelumnya

[.. I also read to increase my own reading comprehension. I always used to evaluate my own reading process to enlighten me whether I have improve or not. Then I can correct my mistake while read before]

The forth question is talking about whether there is an effect of metacognitive strategy on their literal and inferential comprehension in reading. The first students also admitted that she feels by using metacognitive strategy, especially by using paraphrase it helped her to make analysis of the text and to make the conclusion based on her opinion in the end of reading process.

\section{Excerpt \#4}

Narasumber 1: ... Nah yang kaya paraphrase itu juga pengaruh banget sih buat menganalisis teks dan bikin conclusion menggunakan pemikiran sendiri di akhir selesai kita membaca.

[.. such as paraphrase itself it very helped me to analyze the text and to make conclusion use my own opinion in the end of reading]

The second students also admitted that metacognitive strategy affect her literal comprehension, the second student used underlining the words.

\section{Excerpt \#5}

Narasumber 2 : berpengaruh juga... underlining the words, biasanya pakai warna, jadi untuk informasinya ulvi bedakan warnanya. Contoh untuk tokohnya ulvi kasih warna bitu... terus juga kalau misalnya ada kata-kata yang tidak ulvi ketahui atau unknown vocabulary itu aku kasih warna merah.

[it have an influence.. underlining the words, I usually used the color, so I differentiate the color for each information. For example, I use blue color for the character... then I give red color for unknown vocabulary]

The fifth question is talking about whether metacognitive strategy itself help them to understanding the text. Both of students agreed that metacognitive strategy help them to understanding the text.

\section{Excerpt \#6}

Narasumber 1 : skimming dan scanning itu berpengaruh banget buat kemampuan saya memahami sebuah teks. Kalau saya ingin menemukan infromsi lebih detail lagi nih, saya biasanya re-read textnya lagi supaya lebih paham benar dengan isi teks.

[...skimming and scanning are having a big impact on my comprehending text skill. If I want to find more detailed information, I usually re-read the text again for better understanding]

Narasumber 2 : iya sangat membantu buat memahami teks, terutama ...membaca teks lagi itu salah satu teknik yang penting atau utama sih menurut aku buat memahami keseluruhan teksnya

[yes, it very helped to understanding the text, especially... re-read the text again is one of important technic for me to understanding the whole text] 
The last question on forum group discussion is what kind of step, technic or activities that the students use which have a big impact and helped them to understanding literal and inferential aspect on their reading process. The first student chooses underlining the text by using highlight and colourful stabile as the most helpful technic or step when she reads. It also agreed by the second students who said by using colourful colour will help them more to focus read the text.

\section{Excerpt \#7}

Narasumber 1 : aku lebih sering di highlight wordnya atau informasi penting sama vocab yang asing terus juga pakai underlining the word atau menggunakan stabile warna [I often highlight the word or the information or using colorful stabile]

Narasumber 2 : iya, sama. Kaya pakai stabilo atau pulpen warna buat nandain informasinya.

[yes, same. Like using the stabile or colorful pen to mark the information]

They agreed that they also have used visualizing the text as a one of the step that they use while reading. They also said after they visualize the text, then they will use predicting to connect the event happened in the text and analyze it on their own mind. The second students said that predicting are helping her inferential comprehension, she will start to analyze then answer the question by using her own understanding.

Excerpt \#8

Narasumber 1: oh iya kak, aku juga sering pakai itu(visualizing the text). Predicting the text ya, kalau baca novel, kalau baca judul dulu, itu kira-kira tentang apa ya isinya.

[Oh, right. Also use that. Predicting the text, such as when I read the novel, I look at the title, and guess what's inside the book.]

Narasumber 2: ...Jadi abis visualisasi kejadiannya itu, kita langsung prediksi gimana kelanjutannya. Atau untuk soal yang cause effect kan biasanya ada tuh kak, jadi aku sering memvisualisasi kejadiannya, baru pas udah aku bayangin aku predict gimana akibat yg muncul dari scene tersebut baru nanti aku analisis terus aku jawab make pikiran aku sendiri.

[so, after visualizing the event on the text, the we predict the next event. Or for the cause-effect problem, after I visualizing the event of the text then I predict what effect that will appear from that scene. And the last I analyze then I answer by my own opinion.]

In this study, the researcher want to know what are metacognitive strategy used on students' literal and inferential comprehension in reading. After obtaining and collecting data from questionnaires, interviews, and forum group discussion. The researcher analyzed the results to find out metacognitive strategy used on students' literal and inferential comprehension in reading by finding the step that the students use while their reading process happened. The following are the results of questionnaires, interviews, and forum group discussion.
The results of the questionnaire obtained that the students do use the metacognitive strategy in their reading process. Based on the explanation from questionnaire data, it can be said that the fifth semester of English education department students at Pakuan University process a both three high level of metacognitive reading strategies in one of the metacognitive reading. Mokhtari. K and Reichard [2002] states that there are three types of metacognitive reading strategies that can be implemented by the students in comprehending the text (MARSI) such as Global reading strategy (planning), problem solving reading strategy (monitoring) and support reading strategies (evaluating).

The result of questionnaire also supported by the statement who was made based on Cline (2006) who stated that reading is decoding and understanding written text, where understanding determined by the purpose for reading, the context, the nature of the text, and the readers' strategies and knowledge when they read. It is used for the first statement on the questionnaire is talking about where the participants always understand the text that they read.

The results of the interview obtained, it is shown that the three types of Metacognitive strategy are mostly used by the participants on their reading process. The first type is Global Reading Strategies (GLOB). It deals with preparation for reading, including predicting, skimming, applying reading to previous knowledge, decisions on the importance of parts of text and the use of clues in their process of reading, either on pre-reading, while-reading, and even 1skimmimg as one of their step while the process of reading happened. The result also shown that predicting also used by the participant when they read and it can be seen in excerpt \#4.

Another types of metacognitive strategy that appear on the result of interview is the last types of metacognitive strategy that stated by Mokhtari. K and Reichard is Support Reading Strategies (SUPP) category which contains nine indicator such as underlining and taking notes, the use of tools such dictionaries. It is supported from the excerpt \#4 and \#5 that shown the use of underlining while doing the process of reading.

The result of the data from forum group discussion shows that metacognitive strategy mostly used by the students when they do their reading process. They admitted that they use metacognitive strategy in their reading process and did the step and reading technic of metacognitive. They also claimed that metacognitive strategy had an impact on their reading especially on their literal and inferential comprehension. The result was supported from the students' answer of the forth questions talking about the effect of metacognitive strategy on their literal and inferential comprehension. They both agreed of the statement and also gave the researcher example of how the metacognitive strategy help them to understand and aware of their own comprehension.

The result also shows the variety of strategies such as planning, monitoring, and evaluating are adopted by them frequently in order that they can cope with the process of their own reading of reading the text. The discussion shows that the frequency of learners' practice of monitoring strategies for reading comprehension is more than those of planning 
strategies and evaluation strategies, whereas their concern to use planning and evaluating strategies has the same frequently used among the types.

As the conclusion, by the result of this research, it was showed that there are some implementations of metacognitive strategy on students' literal and inferential comprehension in reading. As defined by Hacker [2009:1] that metacognitive strategy is the process of managing thinking and learning while read and the students can manage their own learning by monitoring the process of reading.

Since it deals with a process of learning, this strategy requires the learner to be aware of their learning process which also supported by the statement from Eilers and Pinkley (2006) as quoted by Othman et.al (2014) that stated metacognitive strategy is applied and taught to students to enhance the understanding of a text that has been read. The application of metacognitive strategy during reading and comprehension lessons are believed can help students to think methodically in all three levels of reading process, namely before reading, during reading and after reading.

It is also shown that metacognitive strategy have effect on students literal comprehension by looking through the result of interview and questionnaire that said the participant always make summarizing and also conclude what they have read on the text. Hirsch (2003) also states that Literal comprehension is how the students know prior knowledge about the topic speeds up basic comprehension and leaves working memory free to make connections between the new material and previously learned information, to draw inferences, and to ponder implications.

The participants are able to understand ideas and information explicitly stated in the reading material through information that they have found by identifying the main idea and underlining the text so they can summarize the text they read.

Pennell (2002) who stated that inferential comprehension skill requires a reader to blend the literal content of a selection with prior knowledge, intuition, and imagination for conjecture or to make hypotheses also supports it. It was shown on the result of questionnaire that more than half of the participant use visualizing when they read which is also use to improve their imagination to make hypothesis of what event happened on the text.

\section{CONCLUSION}

In conclusion, the research had proven that metacognitive strategy were used on students' literal and inferential comprehension in their reading process there are Problem-Solving Strategies (PROB) is known and reported to be used by half of the participants. As well as the other two are Global Reading strategies (GLOB) which included preparation for reading, including predicting, skimming. The last is the Support reading strategies (SUPP) which included such as underlining and taking notes, the use of tools such dictionaries. Based on the data gathered and discussion in previous chapter also shows that Metacognitive strategy has an impact to students' literal and inferential comprehension, it shows by using metacognitive strategy, it helps the participant for always make summarizing and also conclude what they have read on the text. Through the use of Metacognitive reading strategy also makes the students aware of their literal and inferential knowledge about the text and it can help them make connections between the new material and previously learned information, to draw inferences, and to ponder implications. The participants are able to understand ideas and information explicitly stated in the reading material through information that they have found by identifying the main idea and underlining the text so they can summarize the text they read which is correlated to literal and inferential comprehension in reading.

\section{REFERENCES}

Aflah, M. N. 2017. The Role of Metacognition in Reading Comprehension. Jurnal Pendidikan Bahasa Vol 6 No.1, 10-22.

Ahmadi, M. R. 2013. The Importance of Metacognitive Reading Strategy Awareness in Reading Comprehension. English Language Teaching, Vol 6 No. 10, ISSN 1916-4742 E-ISSN 19164750.

Ay, Sila. 2009. Academic Reading Strategy and Metacognitive Awareness of University Students. Essay on Turkish Linguistics.

Baker, L. 2002. Metacognition in comprehension instruction. In C. Block \& M. Pressley (Eds.), Comprehension instruction: Research-based best practices. New York: Guilford Press

Berry, J. 2005. Levels of reading comprehension.

Brown, H. Douglas.2000.Teaching by Principles an Interactive Approach to Language Pedagogy. San Fransisco: San Fransisco State University.

C.R. Kothari. 2004. Research Methodology Methods and Techniques Second Revised Edition, India:University of Rajasthan Jaipur.

Creswell, John. 2009. Research Design: Qualitative, Quantitative, and Mixed Methods Approaches: Sage.

Dafiyanti, Sri,. Endang Susilawati dkk The Correlation Between Students' Reading Strategies And Their Reading Comprehension Ability In Reading Academic Text, Pontianak. English Education Study Program, Teacher Training and Education Faculty of Tanjungpura University.

Flavell, J. H. 1976. Metacognitive aspects of problem solving. In L. B. Resnick (Ed.), The nature of intelligence. Hillsdale, NJ: Lawrence Erlbaum Associates.

Flavell, J. H. 1979. Metacognition and cognitive monitoring: A new area of cognitive- developmental inquiry

Hacker, D. J, Dunlosky, L, and Graesser, A. C. 2009. Handbook of metacognition in Education. New York and London : Routledge Taylor \& Francis Group

Harmer, Jeremy. 2015. The Practice of English Language Teaching (fifth edition). England: Pearson.

Iwai, Y. 2011. The Effects of Metacognitive Reading Strategies: Pedagogical Implications for EFL/ESL Teachers.

Li Lai,Ya. Jung Tung, Yu. Ying Luo, Shu. 2008. Theory of Reading Strategies and its Application by EFL 
Learners: Reflections on Two Case Studies. Taipei. Taipei Municipal University of Education.

Mokhtari, K. and Reichard, C. A. 2002. Assessing students' metacognitive awareness of reading strategies. Journal of Educational Psychology, 94(2),249-259

Mokhtari, Kouider and Carla A. Reichard. 2002. Assessing Students' Metacognitive Awareness of Reading Strategies. Oklahoma State University, Journal of Educational Psychology.

Mokhtari, Kouider and Carla A. Reichard. 2002. Assessing Students' Metacognitive Awareness of Reading Strategies. Oklahoma State University, Journal of Educational Psychology.

Ratna S, Anne. 2014. The Use of Cognitive Reading Strategies to Enhance EFL Students' Reading Comprehension. Indonesia, STKIP Garut.

Reza Ahmadi Gilani, Mohammad. 2012. Impacts of Learning Reading Strategy on Students' Reading Comprehension Proficiency, The international Juornal of Language Learning and Applied Linguistics World (IJLLALW), 1(1), Copyright IJLLALW, Norway.

Richards, Jack C and Richards Schmidt. 2002. Longman Dictionary of Language Teaching and applied Linguistic, 3rd Ed., London : Pearson Education Limited.

Suhadi, 2016. Exploring Literal and Inferential Reading Comprehension on Eight Grade. Students. Unpublishing Thesis. Cirebon: Syekh Nurjati Islamic Institut

Pennell, D. 2002. Explicit instruction for Implicit meaning : Strategies for teaching inferential reading comprehension. 